Tarih Kültür ve Sanat Araştırmaları Dergisi

Revue des Recherches en Histoire Culture et Art

مجلة البحوث التاريخية و الثقافية و الفنية
Vol. 7, No. 1, March 2018

Copyright (C) Karabuk University

http://kutaksam.karabuk.edu.tr

\title{
DOI: 10.7596/taksad.v7i1.1362
}

Citation: Duran, E., \& Dolaylar Özkul, ì. (2018). Türk Çocuk Dergileri İle İlgili Öğrenci Görüşlerinin Belirlenmesi. Journal of History Culture and Art Research, 7(1), 467-478. doi:http://dx.doi.org/10.7596/taksad.v7i1.1362

\section{Türk Çocuk Dergileri İle İlgili Öğrenci Görüşlerinin Belirlenmesi*}

\author{
The Determination of Student Views on Turkish Children's Magazines
}

\author{
Erol Duran ${ }^{1}$, Incinur Dolaylar Özkul ${ }^{2}$
}

\begin{abstract}
Children's magazines are literature products that are published in several literary genres and can be considered suitable for children's ages and development levels. Following the developments in scientific subjects, the magazines are eager to develop children's creativity; some magazines try to appeal to children's world by addressing different sports, lifestyles, technology, animals, or geographical themes. These magazines include funny word puzzles, short and clear information, poems, current affairs, experiment with children in scientific studies and supports every page with photographs, cartoons or pictures in accordance with its content. This research aims to evaluate the children's magazines published in Turkey in terms of activities and student opinions. In this study qualitative model is used to evaluate the research questions of "What kind of activities are there in children's magazines?" and "How are student opinions about child magazines?". The data of the research were obtained by document review and interview technique. Data were analyzed by content and descriptive analysis techniques. The data of this study were collected from the numbers of children's magazines published in Turkey during 20162017. There are limited or no puzzles and competitions in the magazines. It seems that puzzles, game, hand-design skill development, experiment-observation activities and the part that comes from you are taken care of. Students prefer magazines with scientific qualities in general. They say that puzzles, crosswords, experiments, games, etc. should be increased in the magazines.
\end{abstract}

Keywords: Children's Literature, Children's magazines, Educational activities, Student opinions.

\footnotetext{
* Bu araştırma, danışmanlığını Doç. Dr. Erol Duran'ın yaptığı ve İncinur Dolaylar Özkul tarafından hazırlanan yüksek lisans tezindeki verilere dayalı olarak hazırlanmıştır. Çalışma, Uşak Üniversitesi Bilimsel Araştırma Projeleri Koordinasyon Birimi tarafından desteklenmiştir (Proje No: 2017/TP032).

${ }^{1}$ Doç. Dr., Uşak Üniversitesi Eğitim Fakültesi, Temel Eğitim Bölümü, Türkiye. E-mail: erol.duran@usak.edu.tr

2 Sınıf Öğretmeni, Millî Eğitim Bakanlığı, Türkiye. E-mail: inciozkul03@gmail.com
} 
Çocuk dergileri, çocukların yaşlarına ve gelişim seviyelerine uygun, duyularına hitap edebilen, birçok edebi türü içinde barındıran, süreli aralıklarla yayınlanan çocuk edebiyatı ürünleridir. Bilimsel konulardaki gelişmeleri takip eden dergiler, çocukların yaratıcılığını geliştirmeye heveslendirirken; bazı dergiler de, farklı sporları, yaşam biçimlerini, teknolojiyi, hayvanları veya coğrafi temaları ele alarak çocukların dünyalarına hitap etmeye çalışılar. Eğlenceli bulmacaların olması, kısa ve net bilgiler sunması, şiirler bulunması, güncel olayların takip edilebilmesi, bilimsel çalışmalar doğrultusunda çocuğa deney yapma olanağı sunması ve içeriğine uygun olarak her sayfanın fotoğraf, karikatür veya resimlerle desteklenmesi, çocuk dergilerinin öne çıkan özellikleridir. Bu araştırma Türkiye'de yayınlanan çocuk dergilerinin etkinlikleri ve öğrenci görüşleri bakımından değerlendirmeyi amaçlamaktadır. Bu çalışma kapsamında: "Çocuk dergilerinde ne tür etkinlikler bulunmaktadır?" ve "Çocuk dergileri ile ilgili öğrenci görüşleri nasıldır?" sorularına cevap aranmıştır. Bu araştırmada nitel model kullanılmıştır. Araştırmanın verileri doküman incelemesi ve görüşme tekniği ile elde edilmiştir. Veriler içerik ve betimsel analiz tekniği ile analiz edilmiştir. Bu çalışmanın verileri, Türkiye'de 2016-2017 yıllarında yayınlanan çocuk dergilerinin sayılarından toplanmıştır. Dergilerde, bilmece ve yarışma etkinliklerine sınırlı sayıda ya da hiç yer verilmediği görülmektedir. Bulmaca, oyun, el-tasarım becerisini geliştirme, deney-gözlem etkinliklerine ve sizden gelenler bölümüne yer verilmesine özen gösterildiği görülmektedir. Öğrencilerin, genel olarak bilimsel nitelik taşıyan dergileri tercih ettikleri görülmektedir. Öğrenciler dergilerde bilmece, bulmaca, deney, oyun vb. etkinliklerin artırılması gerektiğini belirtmektedirler.

Anahtar Kelimeler: Çocuk Edebiyatı, Çocuk dergileri, Eğitsel etkinlikler, Öğrenci görüşleri.

\section{Giriş}

Çocuk dergileri bilimsel gelişmeleri takip edip çocukların yaratıcılığını geliştirmeye heveslendiren, farklı sporları, yaşam biçimlerini, teknolojiyi, hayvanları veya coğrafi temaları ele alarak çocukların dünyasına farklı boyutlar kazandıran süreli yayınlardır. Çocuk edebiyatı ürünlerinin vazgeçilmez bir parçası olan dergilerde, eğlenceli bulmacaların olması, kısa ve net bilgiler sunması, şiirler bulunması, güncel olayların takip edilebilmesi, bilimsel çalışmalar doğrultusunda çocuğa deney yapma olanağı sunması ve içeriğine uygun olarak her sayfanın fotoğraf, karikatür veya resimlerle desteklenmesi çocuk dergilerini diğer edebi ürünlerden öne çıkarmaktadır.

Çocuk dergileri popülerliklerini eğitici okuma kaynakları olarak değerlendirilmesi sayesinde kazanmaktadır (Jones and Reid, 2009: 397). Aylık olağan okuma alıskanlığını da teşvik eden (Waryncia, 2006: 42), tekrar aracı olan ve dil becerisinin gelişimini destekleyen dergiler, sürekli yeni konuları işlemesi, içerdiği edebi metinlerden dolayı çocukların dikkatini çekmesi ve ders kitaplarına oranla çocukları okumaya daha çok yönlendirmesi (Yıldız vd., 2010: 127) yönüyle diğer edebi ürünlerden farklı bir boyut kazanmıştır. Ayrıca dergiler, okuyucunun özel ilgi ve merakına uygun yazılara daha rahat ulaşmasını sağlamaktadır (Coşkun, 2003: 119). Ulutaş ve Çaydaş'a (2013: 761) göre ise çocuk dergileri, çocuğun eğitiminde, gelişmesinde ve topluma katılmasında bilgi, beceri ve yetenekleriyle kendisini gösterebileceği bir eğitim aracıdır.

Temelde ahlaki, gerçek ya da bilgilendirici olan ders kitaplarının yanı sıra, çocuğun en çok eğlenceye intiyacı vardır ve bu ihtiyaç da çocuk edebiyatıyla sağlanmaktadır (Rasul, 2013: 48). Çocuk edebiyatının bir parçası olan çocuk dergileri de çocuğa bilgi edinimini eğlenceli bir şekilde sunmaktadır (Kaptan ve Sürmeli, 2011: 578). Ancak Carus (1996: 439) dergilerde sadece eğlence varsa ve edebi değeri olan hikâyeler yoksa o dergilerin kıymetsiz olduğunu ifade etmektedir. Bu nedenle çocuk dergileri çocuğa eğlenceli bir şekilde sunulurken derginin sayfalarında edebi türlerin hemen hepsinin bulunması önem taşımaktadır. Çünkü dergilerde çeşitli edebi ürünlerin olması dergiyi değerli, eğitici ve etkin hâle getirmektedir. 
İyi bir çocuk dergisinde bulunması gereken nitelikler şunlardır: Kâğıdı, nitelikli ve mat seçilmelidir. Yazılardaki harflerin büyüklüğünün, çocukların yaş ve okuma düzeylerine uygun seçilmesine dikkat edilmelidir. Derginin büyüklüğü, kapak ve sayfa düzeni çocukların okumalarını kolaylaştırıcı biçimde düzenlenmelidir. Küçük çocuklar için yayımlanan dergilerde yazılar bir sayfada bitmiş olmalıdır. Yazıların konu bakımından, çocukların isteğini artırıcı, aynı zamanda dinlendirici ve eğlendirici nitelikte olmasına önem verilmelidir. Dergide makale, masal, öykü, şiir gibi her türden yazıya yer verilmelidir (Kavcar, Oğuzkan ve Sever, 1998: 96-97; Yalçın ve Aytaş, 2008: 235-236).

Çocuk dergilerinin çocuğun davranışlarını olumlu yönde değiştirme ve şekillendirme amacı dergilerin doğrudan çocuklara seslenmesinin gerekliliğini ortaya çıkarmıştır (Alabaş ve Kamer, 2016: 81). Çünkü amacı, çocuğa mesaj iletme olan çocuk dergileri ve çocuklar arasında görsel bir iletişim bulunmaktadır (Sürmeli, 2010: 1). Yani dergiler çocuğa doğru bir şekilde ulaşırsa, mesajlar da çocuk tarafından doğru anlaşılmıs olur. Bu nedenle dergilerdeki fotoğrafların açık ve yalın olmasına özen gösterilmelidir. Resimlerin ve şekillerin de dikkat dağıtmaması için sade ve yalnızca anlatılanı vurgulamasına dikkat edilmelidir.

Çocuk dergileri, birçok çocuk edebiyatı ürününü barındırması açısından farklı bir değere sahiptir (Alabaş, 2012: 254). Çocukları ezberci eğitim-öğretim kültüründen kurtarmak ve onları düşünen, üreten bireyler olarak yetiştirmek için (Karakaya, 2006: 24) onların farklı metin türleriyle karşılaşmasını sağlamak gerekir. Dergide yayınlanacak olan hikâye, şiir, masal, fıkra gibi türler hitap edilen yaş grubuna uygun olarak açık, yalın ve anlaşıır olmalıdır. Çocuğun anlayamayacağı anlatımlardan ve yabancı kelime kullanımından kaçınılmalıdır. Dergi sayfalarında basılan fotoğraf, resim ya da karikatür o sayfada anlatılan konu ile bağlantılı olup çocuğun ilgisini çekmelidir. Çünkü "resimlerle yaşanılan iletişim süreci, çocukların duyu algılarını geliştirir; işitme, bakma, görme, imgeleme yetilerini geliştirmelerine olanak sağlar; soyut kavramları algılamalarını kolaylaştırır" (Sever, 2012: 189).

\section{Araştırmanın Amacı}

Bu çalışmada Türkiye'de yayınlanan çocuk dergilerinde yer alan etkinlikler incelenmiş ve öğrencilerin çocuk dergileri ile ilgili görüşleri belirlenmeye çalışılmıştır. Bu amaçlar doğrultusunda şu sorulara cevap aranmıştır: Türkiye'de (2016 Nisan - 2017 Mart tarihleri arasında) yayınlanan;

1. Çocuk dergilerinde ne tür etkinlikler bulunmaktadır?

2. Çocuk dergileri ile ilgili öğrenci görüşleri nasıldır?

\section{Yöntem}

Bu araştırmada nitel model kullanılmıştır. Araştırmanın verileri betimsel analiz, içerik analizi, doküman incelemesi ve görüşme tekniği ile elde edilmiştir. Doküman incelemesi, araştırılması hedeflenen olgu ya da olgular hakkında bilgi içeren yazılı belgelerin analizini içerir (Yıldııı ve Şimşek, 2003: 140; Tanrı̈ğen, 2012: 239). Görüşme ise ("interview", mülakat), sözlü iletişim yoluyla veri toplama tekniği olup yüzyüze yapılabildiği gibi, telefon vb. anında ses ve resim ileticileriyle de olabilir (Karasar, 2007: 165; Baloğlu, 2009: 93). Bu teknik, konunun derinlemesine anlaşılmasında etkilidir (Bal, 2001: 142).

\section{Çalışma Grubu}

Araştırmanın çalışma grubunu Afyonkarahisar ilinde öğrenim gören 115 ilkokul 4. sınıf öğrencisi oluşturmaktadır. Çalışma grubu, kolay ulaşılabilir örneklem seçim tekniği ile belirlenmiştir. 


\section{Veri Toplama Araçları}

Bu çalışmanın verilerini toplamak için Türkiye'de yayınlanan, 2016 yılının Nisan ayından 2017 yııının Mart ayı sonuna kadar yayınlanan 7 çocuk dergisinin tüm sayıları ve yarı yapılandırılmış görüşme formu kullanılmıştır. Yarı yapılandırılmış görüşsme formunda aşağıdaki sorulara yer verilmiştir:

1. Severek okuduğunuz dergi isimlerini söyleyiniz.

2. Çocuk dergilerinde en çok ilginizi çeken metin türü (şiir, olay yazısı, bilgilendirici yazı gibi) ya da etkinlik (bilmece, bulmaca, deney, oyun vb.) hangisidir? Neden?

3. Aldığınız dergide en beğendiğiniz bölüm hangisidir? Neden?

4. Sizce derginin içeriği ile görselleri uyumlu mudur? Açıklayınız.

5. Size göre dergilerde veya okuduğunuz dergide ne gibi eksiklikler vardır? Siz bir dergi yayınlamış olsaydınız dergilere neler eklerdiniz?

2016 yılının Nisan ayından 2017 yılının Mart ayı sonuna kadar Türkiye'de yayınlanmış ve bu araştırmaya konu olan 7 çocuk dergisi şunlardır: TRT Çocuk, Bilim Çocuk, Diyanet Çocuk, Atlas Çocuk, Araştırmacı Çocuk, Türkiye Çocuk, Çamlıca Çocuk.

\section{Veri Toplama Süreci}

Araştırmada incelenecek dergiler, öğretmen ve öğrencilerle görüşülüp karar verilmiştir. Bu aşamada ayrıca internet üzerinden hangi çocuk dergilerinin güncel olduğu araştırmacı tarafından araştırılmıştır. Alınan çocuk dergileri Afyonkarahisar Selçuklu illkokulu'nda 120 ilkokul 4. sınıf öğrencisine ve 4 sınıf öğretmenine inceletilmiş ve böylece onların dergilere dokunmaları, görsellerini, içeriğini görüp irdelemeleri sağlanmıştır. Öğrenciler başlangıçta dergilerin hediyelerine göre değerlendirme yapmışlardır. Bu durum üzerine öğrencilere "Hediyeler verilmeseydi hangi dergiyi tercih ederdiniz?" diye sorularak daha objektif sonuçlara ulaşıımıştır. Ardından öğrencilerden en beğendikleri 3 dergi isminin araştırmacı tarafından dağıtılan kâğıtlara yazılması istenmiştir. Böylece hangi çocuk dergilerinin araştırma sürecine alınması gerektiği kararına varılmıştır. Araştırmaya öğrenci ve öğretmen görüşleri doğrultusunda ilkokul düzeyi çocuklarına hitap eden 7 çocuk dergisi ile devam edilmesi kararlaştırılmıştır. Bu dergiler: "A Dergisi", "B Dergisi”, “C Dergisi”, “D Dergisi”, “E Dergisi”, “F Dergisi”, “G Dergisi” olarak kodlanmıştır.

Çocuk dergilerinde ne tür etkinlikler olduğunu belirlemek için çocuk dergileri incelenmiş ve elde edilen etkinlikler tek tek not edilmiştir. Ardından uzman görüşü alınıp bu doğrultuda bir tablo hazırlanarak çocuk dergilerinde bulunan etkinliklerin frekansları belirleme çalışmalarına başlanmıştır. Dergiler sayfa sayfa irdelenerek bir dergide her etkinlikten kaç tane olduğu tespit edilmiştir.

Ayrıca öğrenci görüşlerini almak için yarı yapılandırılmış görüşsme formu hazırlanmıştır. Görüşme formunun hazırlama sürecinde soruların çocuk dergilerindeki konu alanlarını, metin türlerini, görselleri ve etkinlikleri kapsamasına özen gösterilmiştir. Yarı yapılandııılmış görüşme formu uzmanlara gösterilerek uzman görüşü doğrultusunda sorulara şekil verilmiştir.

\section{Verilerin Analizi}

Araştırmada iki analiz yöntemi kullanılmıştır: Birinci alt problem için betimsel analiz ve içerik analizi, ikinci alt problem için ise tematik kodlama yapılmıştır.

Betimsel analizin amacı, elde edilen verileri düzenlenmiş ve yorumlanmış biçimde okuyucuya sunmaktır. Betimsel çözümlemede elde edilen veriler önce mantıklı ve anlaşılır biçimde betimlenir, sonra da yorumlanıp, neden- sonuç ilişkileri incelenir ve sonuçlara ulaşılır (Yıldırım ve Şimşek, 2003: 158-159). İçerik 
analizi ise, belirli kurallara dayalı kodlamalarla kitap, kitap bölümü, mektup, tarihsel dokümanlar, gazete başlıkları ve yazıları gibi bir metnin bazı sözcüklerinin daha küçük içerik kategorileri ile özetlendiği sistematik, yinelenebilir bir tekniktir (Sert vd., 2012: 2).

\section{Bulgular}

Araştırmanın bulguları, alt problem sırası dikkate alınarak açıklanmıştır.

\section{Birinci Alt Probleme ílişkin Bulgular ve Yorumlar}

Araştırmanın birinci alt problemi olan "Türkiye'de yayınlanan çocuk dergilerinde ne tür etkinlikler bulunmaktadır?" sorusu için elde edilen veriler Tablo 1'de sıralanmıştır.

Tablo 1. Türkiye'de 2016 Nisan-2017 Mart Tarihleri Arasında Yayınlanan Çocuk Dergilerinin Etkinliklere Göre Dağılımı

\begin{tabular}{|c|c|c|c|c|c|c|c|c|c|c|c|}
\hline $\begin{array}{l}\text { Dergi } \\
\text { Adı }\end{array}$ & 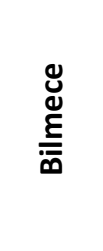 & 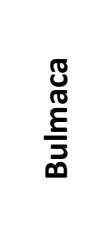 & $\overbrace{\delta}^{5}$ & 胥 & 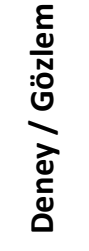 & 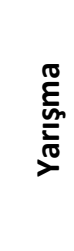 & 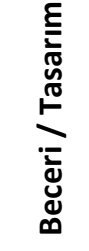 & $\stackrel{\text { ğ }}{2}$ & 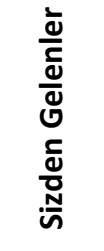 & 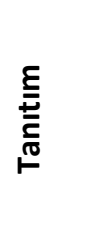 & $\frac{\varepsilon}{\frac{\varepsilon}{\pi}}$ \\
\hline $\begin{array}{l}\text { A } \\
\text { Dergi } \\
\text { si }\end{array}$ & - & $\begin{array}{c}20 \\
(\% 1 \\
2)\end{array}$ & $\begin{array}{c}19 \\
(\% 1 \\
1)\end{array}$ & - & $\begin{array}{c}2 \\
(\% 1)\end{array}$ & - & $\begin{array}{c}27 \\
(\% 16 \\
)\end{array}$ & - & $\begin{array}{c}38 \\
(\% 23)\end{array}$ & $\begin{array}{c}61 \\
(\% 37)\end{array}$ & $\begin{array}{c}167 \\
(\% 100)\end{array}$ \\
\hline $\begin{array}{c}\text { B } \\
\text { Dergi } \\
\text { si }\end{array}$ & $\begin{array}{c}19 \\
(\% 4)\end{array}$ & $\begin{array}{c}83 \\
(\% 1 \\
6)\end{array}$ & $\begin{array}{c}5 \\
(\% 1 \\
\text { ) }\end{array}$ & $\begin{array}{c}4 \\
(\% 1)\end{array}$ & - & - & $\begin{array}{c}12 \\
(\% 2)\end{array}$ & $\begin{array}{c}11 \\
(\% 2)\end{array}$ & $\begin{array}{c}378 \\
(\% 74)\end{array}$ & - & $\begin{array}{c}512 \\
(\% 100)\end{array}$ \\
\hline $\begin{array}{c}\text { C } \\
\text { Dergi } \\
\text { si }\end{array}$ & - & $\begin{array}{c}70 \\
(\% 1 \\
5)\end{array}$ & $\begin{array}{c}6 \\
(\% 1 \\
\text { ) }\end{array}$ & - & $\begin{array}{c}22 \\
(\% 5)\end{array}$ & - & $\begin{array}{c}14 \\
(\% 3)\end{array}$ & $\begin{array}{c}1 \\
(\% 0,2 \\
)\end{array}$ & $\begin{array}{c}325 \\
(\% 70)\end{array}$ & $\begin{array}{c}24 \\
(\% 5)\end{array}$ & $\begin{array}{c}462 \\
(\% 100)\end{array}$ \\
\hline $\begin{array}{c}\text { D } \\
\text { Dergi } \\
\text { si }\end{array}$ & - & $\begin{array}{c}38 \\
(\% 2 \\
1)\end{array}$ & $\begin{array}{c}2 \\
(\% 1 \\
)\end{array}$ & - & $\begin{array}{c}10 \\
(\% 5)\end{array}$ & $\begin{array}{c}12 \\
(\% 7)\end{array}$ & $\begin{array}{c}3 \\
(\% 2)\end{array}$ & $\begin{array}{c}1 \\
(\% 0,5 \\
)\end{array}$ & - & $\begin{array}{c}118 \\
(\% 64)\end{array}$ & $\begin{array}{c}184 \\
(\% 100)\end{array}$ \\
\hline$\underset{\text { Dergisi }}{\mathrm{E}}$ & - & $\begin{array}{c}14 \\
(\% 5)\end{array}$ & $\begin{array}{c}10 \\
(\% 4)\end{array}$ & - & $\begin{array}{c}12 \\
(\% 4)\end{array}$ & - & $\begin{array}{c}17 \\
(\% 6)\end{array}$ & $\begin{array}{c}1 \\
(\% 0,3)\end{array}$ & $\begin{array}{c}205 \\
(\% 76)\end{array}$ & $\begin{array}{c}12 \\
(\% 4)\end{array}$ & $\begin{array}{c}271 \\
(\% 100)\end{array}$ \\
\hline $\begin{array}{c}\mathbf{F} \\
\text { Dergi } \\
\text { si }\end{array}$ & $\begin{array}{c}68 \\
(\% 8)\end{array}$ & $\begin{array}{c}149 \\
(\% 1 \\
8)\end{array}$ & $\begin{array}{c}21 \\
(\% 3 \\
1\end{array}$ & $\begin{array}{c}280 \\
(\% 34)\end{array}$ & - & - & $\begin{array}{c}6 \\
(\% 1)\end{array}$ & - & $\begin{array}{c}66 \\
(\% 8)\end{array}$ & $\begin{array}{c}231 \\
(\% 28)\end{array}$ & $\begin{array}{c}821 \\
(\% 100)\end{array}$ \\
\hline $\begin{array}{c}\text { G } \\
\text { Dergi } \\
\text { si }\end{array}$ & $\begin{array}{c}1 \\
(\% 0,3 \\
)\end{array}$ & $\begin{array}{c}147 \\
(\% 5 \\
1)\end{array}$ & - & $\begin{array}{c}49 \\
(\% 17)\end{array}$ & $\begin{array}{c}8 \\
(\% 3)\end{array}$ & - & $\begin{array}{c}6 \\
(\% 2)\end{array}$ & - & $\begin{array}{c}33 \\
(\% 11)\end{array}$ & $\begin{array}{c}44 \\
(\% 15)\end{array}$ & $\begin{array}{c}288 \\
(\% 100)\end{array}$ \\
\hline
\end{tabular}


A Dergisi ve diğer 6 dergi (B Dergisi, C Dergisi, D Dergisi, E Dergisi, F Dergisi ve G Dergisi) 2016 Nisan ayından başlayarak bir yıl boyunca incelenmiş ve tablolardaki sonuçlar elde edilmiştir. Tablo 7'ye göre A Dergisi'nde en fazla 2 bulmaca bulunan sayılar 2016 Nisan, 2016 Mayıs, 2016 Haziran, 2016 Temmuz, 2016 Ağustos, 2016 Ekim, 2016 Kasım ve 2016 Aralık'tır. 1 bulmaca bulunan sayılar ise 2016 Eylül, 2017 Ocak, 2017 Şubat ve 2017 Mart'tır. Verilere bakıldığında en fazla oyuna 2016 Ağustos (9) sayısında yer verilmiştir. Buna karşılık 2017 Mart sayısında oyun etkinliği yer almamışır. Bu iki sayının dışındaki tüm sayılarda 1 oyuna yer verilmiştir. A Dergisi'nde 2017 Şubat ve 2017 Mart sayılarında 1 deney / gözlem etkinliği bulunurken; derginin diğer sayılarında deney / gözlem etkinliğine yer verilmemiştir. En fazla 3 beceri / tasarım etkinliği bulunan dergide en az 2 beceri / tasarım etkinliği bulunmaktadır. Çocukların kendi emeklerinin, duygularının ve düşüncelerinin sergilendiği bölüm olan "Sizden Gelenler" kısmında en fazla 4 (2016 Eylül, 2016 Aralık) ürün; derginin diğer sayılarında ise 3 "Sizden Gelenler" ürünü tespit edilmiştir. Bu bölüme gönderilen resim ve mektuplar da yaş düzeyi açısından farklıık göstermektedir. Örneğin 2016 Nisan sayısının "Küçük Sanatçılar" bölümünde hem 8. sınıf öğrencisine hem de 3. sınıf öğrencisine ait etkinlik bulunmaktadır. Oysa bu iki öğrenci gelişim açısından farklıık gösterdiğinden ikisini aynı yönden değerlendirmek yanlış olabilir. Dergide en fazla 8 tanıııma (2017 Mart); en az 2 tanıtıma (2016 Haziran) yer verilmiştir. Tablo 7'ye göre A Dergisi'nde bilmece, mizah, yarışma ve test etkinliklerine rastlanmamıştır.

\section{ikinci Alt Probleme ilişkin Bulgular ve Yorumlar}

Araştırmanın ikinci alt problemi olan "Türkiye'de yayınlanan çocuk dergileri ile ilgili öğrenci görüşleri nasıldır?" sorusu için elde edilen tematik kodlama sonuçları Tablo 2'de sıralanmıştır.

Tablo 2. Türkiye'de 2016 Nisan-2017 Mart Tarihleri Arasında Yayınlanan Çocuk Dergileri İle Illgili Öğrenci Görüşleri

\begin{tabular}{|c|c|c|c|}
\hline Kategori & Alt Kategori & Frekans & Örnek Açıklama \\
\hline \multirow{4}{*}{ 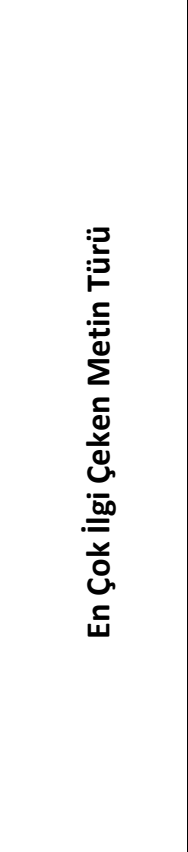 } & Fikra & 19 & $\begin{array}{l}\text { Ö111: Çocuk dergilerinde en çok ilgimi çeken metin türü } \\
\text { fıkralardır. Çünkü ben gülmeyi çok seven biriyim. } \\
\text { Ö114: Ben metin türü olarak fıkraları seviyorum. Çünkü } \\
\text { eğlenceli ve komiktir. }\end{array}$ \\
\hline & Şiir & 8 & $\begin{array}{l}\text { Ö20: Şiirler dikkatimi çekti; çünkü şiir okumayı seviyorum. } \\
\text { Ö110: Şiirler dikkatimi çekti. Çünkü şiirler eğlenceli } \\
\text { olabiliyor. }\end{array}$ \\
\hline & Masal & 4 & $\begin{array}{l}\text { Ö21: Masal. Çünkü masallar okuyucunun hayal gücünü } \\
\text { geliştirir. } \\
\text { Ö59: Masal. Çünkü masal dinlemeyi severim. Bana } \\
\text { eğlenceli gelir. }\end{array}$ \\
\hline & Gezi Yazısı & 1 & $\begin{array}{l}\text { Ö10: En çok ilgimi çeken metin türü gezi yazısıdır. Çünkü } \\
\text { farklı şehirleri okumak çok hoşuma gidiyor. }\end{array}$ \\
\hline 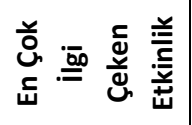 & & & $\begin{array}{l}\text { Ö100: Deney yapmayı seviyorum. Çünkü yeni bir buluş } \\
\text { yapmak istiyorum ve Fen ve Teknoloji dersini çok }\end{array}$ \\
\hline
\end{tabular}




\begin{tabular}{|c|c|c|c|}
\hline & Deney & 35 & $\begin{array}{l}\text { seviyorum. } \\
\text { Ö112: Bana göre deney. Çünkü hem bir şeyler } \\
\text { öğreniyorum hem de etkinlik sırasında eğlenceli vakit } \\
\text { geçiriyorum. }\end{array}$ \\
\hline & Bulmaca & 16 & $\begin{array}{l}\text { Ö78: Bulmacayı çok seviyorum. Çünkü eğlenceli. Ayrıca } \\
\text { onların çözümünü bulmaktan zevk alıyorum. } \\
\text { Ö85: Bulmaca çünkü bulmacaları çözerken eğleniyorum. }\end{array}$ \\
\hline & Oyun & 15 & $\begin{array}{l}\text { Ö14: A Dergisi'ndeki Rafadan Tayfa'nın anlattığı oyunları } \\
\text { çok seviyorum. Yeni oyunlar öğreniyorum. } \\
\text { Ö79: Oyun. Çünkü çok eğlenceli. }\end{array}$ \\
\hline & Bilmece & 10 & $\begin{array}{l}\text { Ö29: Bilmeceler ilgimi çekti. Çünkü sonuçlarını bulurken } \\
\text { eğleniyorum. } \\
\text { Ö77: Bilmece. Çünkü eğlenirken bilgi ediniyorum. } \\
\text { Ö90: Bilmeceler dikkatimi çekti. çünkü çok zor } \\
\text { bilmecelerin sonuçlarını bulurken eğleniyorum. }\end{array}$ \\
\hline & Tasarım & 8 & $\begin{array}{l}\text { Ö25: Tasarımlar ilgimi çekiyor. Çünkü yeni şeyler } \\
\text { tasarlıyorum. } \\
\text { Ö87: Tasarımlar ilgimi çekiyor. Çünkü çok eğlenceli. }\end{array}$ \\
\hline \multirow{3}{*}{ 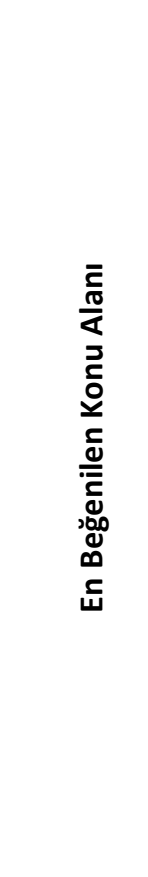 } & $\begin{array}{c}\text { Sağlık, Spor ve } \\
\text { Oyun }\end{array}$ & 47 & $\begin{array}{l}\text { Ö105: Benim beğendiğim derginin en güzel bölümü } \\
\text { karikatürdür. Çünkü eğlenceli ve komik oluyor. Rafadan } \\
\text { Tayfa'ının oyun bölümünü de seviyorum. } \\
\text { Ö113: Oyunlu karikatürlerdir. Çünkü mizah duygusu çok } \\
\text { yüksek ve çok eğlendiriyor. }\end{array}$ \\
\hline & $\begin{array}{l}\text { Bilim ve } \\
\text { Teknoloji }\end{array}$ & 20 & $\begin{array}{l}\text { Ö22: En beğendiğim bölüm deneyler; çünkü deneylerin } \\
\text { sonucunu görmek beni heyecanlandırıyor. } \\
\text { Ö40: Deney bölümü. Çünkü deney yapmayı seviyorum. } \\
\text { ö98: En sevdiğim bölüm deneydir. Çünkü keyif alıyorum } \\
\text { ve eğleniyorum. }\end{array}$ \\
\hline & Çevre & 16 & $\begin{array}{l}\text { Ö17: Hayvanlar bölümünden hoşlandım. Çünkü kış } \\
\text { uykusuna yatan hayvanlar hakkında bilgilendim. } \\
\text { Ö26: A Dergisi'ndeki ibi ile Tosi'nin gezi yazıları bölümünü } \\
\text { beğendim. Çünkü öğreticidir. }\end{array}$ \\
\hline \multirow[t]{2}{*}{$\begin{array}{l}\text { İçerik ile } \\
\text { Görsel } \\
\text { Uyumu }\end{array}$} & Uyumlu & 115 & $\begin{array}{l}\text { Ö5: Uyumlu ama ben olsaydım biraz daha eğlenceli şeyler } \\
\text { yapardım. } \\
\text { Ö8: Bence derginin içeriği ve görselleri uyumlu. }\end{array}$ \\
\hline & Uyumlu değil & --- & --- \\
\hline
\end{tabular}




\begin{tabular}{|c|c|c|c|}
\hline \multirow[t]{2}{*}{$\begin{array}{c}\text { Dergilere } \\
\text { Eklemek } \\
\text { İstediklerini } \\
\text { z }\end{array}$} & Var & 62 & $\begin{array}{l}\text { Ö97: Beğendiğim dergilerde sadece bir tane deney var. } \\
\text { Karikatürlere çok fazla yer verilmiş. Oysa deney daha } \\
\text { fazla olmalıydı. Ben bir dergi yayınlasaydım daha fazla } \\
\text { deney eklerdim ve karikatürleri azaltırdım. } \\
\text { Ö99: Dergilerde test bölümleri yok. Eğer ben bir dergi } \\
\text { yayınlamış olsaydım içine bilgilendirici yazı, şiir ve } \\
\text { hayvanlarla ilgili masal, Nasreddin Hoca fıkraları, } \\
\text { deneyler bulmaca ve bilmece eklerdim. } \\
\text { Ö102: Maç sonuçları eksik. Ben maç sonuçlarını, } \\
\text { takımların durumlarını küçükyazılarla özetlerdim. }\end{array}$ \\
\hline & Yok & 53 & $\ldots \ldots \ldots$ \\
\hline
\end{tabular}

"Çocuk dergilerinde en çok ilginizi çeken metin türü ya da etkinlik hangisidir? Neden?" sorusunun cevaplarında, etkinliklerin metin türlerine göre daha fazla ilgi gördüğü Tablo 2'de açıkça ortaya konmuştur. Öğrenciler tarafından etkinliklerin genel olarak eğlenceli bulunması sebebiyle ilgi çekici olduğu ifade edilmiştir. Etkinlikler içinde en fazla deneyler dikkat çekmiştir. Ayrıca dergi içeriğinde bulunan metin türlerinden en fazla fıkra tercih edilmiştir. Okuyucuların verdikleri cevaplara bakılırsa fıkralar da aynı zamanda etkinlik türü olarak değerlendirilmiş ve güldürücü, eğlendirici olduğundan metin türleri içinde daha fazla tercih edilmiştir. Bunun yanı sıra şiir, masal, gezi yazısı vb. türler öğrenciler tarafından daha az ilgi görmüştür.

"Çocuk dergilerinde en beğendiğiniz bölüm hangisidir?" sorusu sorulduğunda en beğenilen konu alanının "Sağlık, Spor ve Oyun" olduğu görülmektedir. Öğrenciler çocuk dergilerinde genel olarak spor ve oyun bölümlerini okumaktan hoşlandıklarını belirtmişlerdir. Daha sonra "Bilim ve Teknoloji" ve "Dünya ve Çevre" konu alanlarını okumak istediklerini açıklamışlardır.

"Sizce beğendiğiniz derginin içeriği ile görselleri uyumlu mu?" sorusuna karşılık olarak bütün öğrenciler çocuk dergilerinde içerik ile görsellerin uyumlu olduğunu belirtmişlerdir. Ancak bazı öğrenciler dergilerin daha eğlenceli görseller ekleyebileceklerinden bahsetmişlerdir:

"Size göre dergilerde veya beğendiğiniz dergide ne gibi eksiklikler vardır? Siz bir dergi yayınlamış olsaydınız derginize neler eklerdiniz?" sorusuna "Beğendiğim dergide eksiklik var." cevabını vermiştir. Bu öğrenciler deneylerin, şiirlerin, bilmecelerin, bulmacaların, fıkraların ve benzerlerin eklenebileceğini ve sayılarının artırılabileceğini açıklamıştır. Bazı öğrenciler ise spor müsabakalarının sonuçlarının ve takımların durumlarının eklenebileceğini belirtmiştir. 53 ilkokul 4. sınıf öğrencisi ise "Beğendiğim dergide eksiklik yok." yanıtını vermiştir.

\section{Sonuç ve Tartışma}

Araştırmanın bulgulara ışığında oluşan sonuçlar alt problem sırası dikkate alınarak tartışılmışır. Öncelikle, dergi içeriğinde yer alan etkinliklerle ilgili ulaşılan sonuçlar; daha sonra ise öğrencilerin dergiler ile ilgili görüşleri tartışılmıştır.

Dergilerde bilmece etkinliklerine sınırlı sayıda yer verilmiş ya da hiç yer verilmemiştir. Oysa bilmece, çocukların akıl yürütme, problem çözme, anlama, yorumlama gibi becerilerini geliştirdiği için çocuk dergilerinde bulunması önemlidir. Bilmeceler çocukların kelimeler ile nesneler arasında bağlantılar kurmaları, zihin alıştırmaları yapmaları ve aynı zamanda da hoş vakit geçirebilmeleri açısından da önemlidir (Balcı, 2014: 35). 
Dergilerde genellikle bulmaca etkinlikleri bulunmaktadır. Tanrıkulu'na (2014: 316) göre öğrencideki problem çözme ve akıl oyunları isteği bilmece ve bulmacayı ilgi çekici hâle getirmektedir. Bazı çocuk dergilerinde dergi içeriğine bağlı olarak kare bulmaca, sayı yerleştirme, çengel bulmaca gibi klasik bulmacalar yerine bilimsel içerikli, özgün bulmacalara yer ayrılmıştır. Bu tür bulmacalarla çocuk her zaman karşılaşmadığından onları çözmek için daha da heveslenebilir. Ayrıca özgün nitelikteki bulmacalarda birden çok kural bulunduğu için çocuk bu tarz bulmacaları çözerken akıl yürütme, çok yönlü düşünme gibi zihinsel becerileri kullanabilir.

Çocukların farklı oyunlar oynayabilmeleri ve bu oyunların nasıl oynandığını öğrenebilmeleri için bazı çocuk dergileri oyun etkinliklerine yer vermişlerdir. Tanrıkulu'na (2014: 316) göre "çocuk dergilerindeki oyunlar çocukluk çağındaki öğrencilerin ilgisini çekmektedir." Dergilerdeki bazı oyunlar çocukların televizyonda gördükleri çizgi film karakterleri ile anlatılmıştır. Yiğitbaşı (2014: 51) da A Dergisi'nde çocukların evde ya da dışarıda oynayabilecekleri basit ve pratik oyunlara yer verildiğini belirtmiştir. Dergilerde yetersiz de olsa öğrencileri güldürmeye ve onları eğlendirmeye yönelik olarak hazırlanan mizah öğelerine de rastlanmıştır. Mizah etkinlikleri kimi dergide fıkra, kimi dergide komik sözler şeklinde yerini almıştır.

Deney ve gözlem etkinlikleri her dergide bulunmasa da incelenen birçok dergide bu etkinliğe yer verilmesine özen gösterilmiştir. Çocukların bilimsel olayları anlamasını kolaylaştıran ve onlara yaparak yaşayarak öğrenme imkânı tanıyan deney ve gözlem etkinlikleri görsellerle desteklenerek yalın anlatımlarla açıklanmıştır. Öğrenci görüşlerine göre çocukların kolaylıkla uygulayabildikleri bu etkinlikler ders ortamından uzak olduğundan ve zorunlu olmadığından çocuklar tarafından ilgiyle karşılanmaktadır. Bu etkinlikler öğrencilerde bir şeyleri başarabilme duygusu geliştirdiği gibi onları yeni ürünler üretmek için cesaretlendirmektedir. Ayrıca bilimsel nitelikteki deney çalışmaları öykülerle desteklenerek çocuklara sunulabilmektedir. Böylece çocuğun hem bilgisi gelişmekte hem de edebiyat eksikliği giderilmektedir. Zur’a (2014: 336) göre çocuk dergilerinde sunulan bilim etkinlikleri, çocuklar için edebiyat ürünü olan öykü anlatımını eğlence uğruna zenginleştirmenin bir aracı değil, kendi başına bir amaç ve ulusun gelişimi için gerekli bir araçtır.

Yarışma etkinliklerine çocuk dergilerinde fazla yer verilmediği dikkat çekmektedir. Hâlbuki çocuk, yarışmalara katılarak hem kendi çalışmalarını başkalarıyla paylaşma imkânı bulabilir hem de yarışmayı kazandığında özgüven, başarı gibi birçok duyguyu tadabilir.

El becerisi konusunda yatkınlığı olan ve yeni tasarımlar yapmayı seven çocuklar için beceri/tasarım etkinliklerine de yer verilmiştir. Bu etkinlikler çocuklarda yeni bir ürün ortaya çıkarma arzusu geliştirebildiği gibi tasarım veya beceri ürününün nasıl olacağı konusunda merak duygusu da oluşturabilir. Çocukların kişisel olarak gelişimlerini gösteren testlerle sık olmasa da zaman zaman karşılaşılmaktadır.

Çocuklar özgün olarak tasarladığı resim, şiir ve mektupları başkalarına gösterebilme fırsatını Sizden Gelenler bölümünde bulabilmektedir. Bu bölümde çocuk süreli olarak yayınlanan ulusal bir dergide kendi cümlelerini, duygularını, çizimlerini sergileyebilmektedir. Ercan ve Akpınar (2014: 126) araştırmasında incelemiş olduğu derginin bazı sayılarında okuyuculardan gelen mektuplara yer verildiğini ve mektuplarını basılmıs halde gören okuyucuların dergiye olan ilgilerinin artabileceğini belirtmiştir. Balcı (2014: 36) dergide yayınlanan okuyucu mektuplarının derginin belli bir okuyucu kitlesine hitap ettiğinin ve beğenildiğinin göstergesi olduğunu açıklamıştır. Yıldız'a (2012: 387) göre derginin okuyucuları ile iyi bir iletişim kurması ve sevilmesi nedeniyle okuyucuların çalışmalarının yayınlandığı bölümler değişmez köşelerden biri olmuştur. Yiğitbaşı (2014: 51) da, çocuklar tarafından gönderilen fotoğraf ve resimler sayesinde çocukların, dergide kendilerinden bir iz ve parça bulduklarını ve aidiyet duygusunu yaşadıklarını belirtmiştir.

Nitelikli çocuk dergileri bir reklam aracı olarak potansiyel güçtür (Lindquist, 1979). Çünkü çocuk dergileri genelde yayınlarda, çizgi romanlarda, oyunlarda ve bulmacalarda gizli reklamlar taşırlar (Jones, Wiese, 
Fabrianesi, 2008: 168). Ancak yalnızca ticari kaygıları olan dergiler bu gücü öğrenciye yarardan çok zarara dönüştürmektedir. Dergilerdeki pazarlama ürünleri çocuğu olumlu durumlara yönlendirebildiği kadar olumsuz ve istenmeyen durumlarla da karşılaştırabilir. Çocuk dergilerindeki pazarlama biçimlerinin çocukların yiyecek tercihleri ve beslenme davranışları üzerinde de etkileri vardır. (Kelly and Chapman, 2007: 290). Örneğin çocuk dergilerindeki reklamlar faydalı ise çocuk, dergi reklamında gördüğü üründen yarar sağlayacaktır; ancak çocuğun sağlığına zararlı ürünlerin reklamı yapılıyorsa bu reklam çocuğu olumsuz durumlara sürükleyecektir. Aslında, çocuk dergilerinin okur kitlesi görünüşte ebeveyn onayına sahip olmakla birlikte, ebeveynler için gıda promosyonunun kapsamı ve doğası hakkında araştırma verileri çok sınırlıdır (Jones, Gregory ve Kervin, 2012: 5). Bu sebeple ebeveynler çocuk dergilerini satın alırken dergilerin amaçlarının farkına varmalı çocuklarına katkı sağlayacak en iyi dergiye ulaşmayı hedeflemelidir.

Çocuk dergilerindeki tanıtımların özenle hazırlanması önem taşımaktadır. Tanıtım veliler veya öğretmenler önünde küçük çocukların 'özerklik' imajını güçlendirme eğilimindedir (Carvalho, 2013: 179). Devlet kurumu tarafından desteklenerek yayınlanan dergilerde kar amacı güdülmediğinden tanıtımlara ya sınırlı sayıda yer verilmiş ya da yer verilmemiştir. Dedeoğlu ve diğerlerinin (2011: 36) ve Demiryürek (2012: 1031) çalışmalarında devlet kurumu tarafından desteklenen dergilerde piyasada reklâmlara ölçülü şekilde yer verildiği ya da hiç yer verilmediği ve kar amacı güdülmediği vurgulamışlardır. Buna karşılık bu araştırma kapsamında incelenen bazı çocuk dergilerinde şofben, tatil ev veya özel hastane tanıtımlarına yer verilmiştir. Oysa bahsi geçen tanıtımlar çocukların düzeyine uygun değildir.

Jones, Wiese \& Fabrianesi'ye (2008: 184) göre, dergilerdeki ürün tanıtımlarının çoğunluğu bir oyun veya yarışmalarla ilişkilidir ve çocuğun ödül kazanma fırsatlarına bağlıdır. Fakat yapılan bir araştırmada, çocukların çocuk dergilerinde kullanılan pazarlama stratejilerini fark ettikleri ve bu stratejilere karşı duyarlı oldukları belirlenmiştir (Jones, Mannino ve Green, 2010: 2116).

Araştırmanın ikinci alt problemi olan "Türkiye'de yayınlanan çocuk dergileri ile ilgili öğrenci görüşleri nasıldır?” en çok ilgi çeken etkinliğin deney; metin türünün fıkra olduğu tespit edilmiştir. Öğrenci görüşlerinde en beğenilen konu alanı çocukları eğlendirici etkinlikleri kapsayan "Sağlık, Spor ve Oyun"dur. Öğrencilerin en beğendikleri diğer konu alanları ise sırasıyla "Bilim ve Teknoloji" ve "Dünya ve Çevre"dir. Dergilerin içeriği ile görsellerini uyumlu bulan öğrenciler dergilerde daha fazla masal, deney, bilmece, bulmaca ve karikatür bulunmasını istediklerini açıklamışlardır. Dergiler öğrenci görüşleri açısından değerlendirildiğinde öğrencilerin genel olarak bilimsel nitelik taşıyan dergilerden hoşlandıklarını ve bu dergilerde yalnızca bilgilendirici metinlere değil bunun yanında kendilerinin eğlenmesini, dinlenmesini bir taraftan da bilgilenmesini ve düşünmesini sağlayan bilmece, bulmaca, deney, fıkra, karikatür vb. etkinliklere daha fazla yer verilmesi gerektiği sonucuna ulaşılmıştır. Bu da çocukların, çocuk dergileri sayesinde hem eğlenmek hem de bilgilenmek istediklerini göstermektedir.

Çocuk dergilerinde bilgilendirici yazılar olduğu kadar eğlenceli etkinliklere de yer verilmesi derginin niteliğini artırabilir. Dergiler tamamen öğretici ya da tamamen eğlenceli olmamalıdır. Dergi bir taraftan eğlendirirken diğer taraftan bilgi verip öğretebilmelidir. Böylece çocuk, dergiyi okurken sıkıcı bilgilerle dolu sayfalardan uzaklaşabilir.

Iyi bir çocuk dergisi çocukların eleştiri yapabilmesini ve araştırma becerisini destekleyebilmelidir. Ayrıca çocuklara özgür düşüncelerini açıklayabilecek imkânlar vermeli; onların küçük dünyalarından büyük pencereler açabilmelidir. Böylece çocukların üst düzey düşünme becerileri gelişecektir. Bu niteliklerde de belirtildiği üzere çocuklar için hazırlanan her yapıt gibi çocuk dergileri de derin bir inceleme sonucunda çocuklara sunulmalıdır. Aksi takdirde çocuk dergileri sıkıcı olmakla kalmayıp, çocukların dış dünyaya açılan kapılarından biri de kapanmış olabilir. 


\section{Kaynakça / References}

Alabaş, R. (2012). Çocuk Duygusu Dergisi'nde yer Alan Şiirlerin Tema Bakımından İncelenmesi. 3. Ulusal Çocuk ve Gençlik Edebiyatı Sempozyumu (Bildiriler ve Atölye Çalışmaları) 2011, (Haz. Sedat Sever). Ankara: Ankara Üniversitesi Basımevi. 253-260.

Alabaş, R. \& Kamer, S. T. (2016). Afacan Çocuk Gözü Dergisi ve Çocuğun Vatandaş Olarak Eğitimi. International Periodical for the Languages, Literature and History of Turkish or Turkic, 11 (3), 77-92.

Bal, H. (2001). Bilimsel Araştırma Yöntem ve Teknikleri. Isparta: SDÜ Basımevi.

Balcı, A. (2014). Çocuklara Kıraat Dergisi. Bilig, 68, 25-42.

Baloğlu, B. (2009). Sosyal Bilimlerde Araştırma Yöntemi. İstanbul: Der.

Carus, M. (1996). Children's Magazines. International of Children's Literature. Hunt, P. (ed.), London: Routhedge, s.438-452.

Carvalho, F. F. (2013). Social Semiotics and Literacy: A Case Study about the Social Meanings Constructed by Ads of a Children's Magazine. Australian Journal of Language and Literacy, 36(3), 169-180.

Coşkun, E. (2003). Çeşitli Değişkenlere Göre Lise Öğrencilerinin Etkili Okuma Becerileri Ve Bazı Öneriler. TÜBAR-XIII, 101-130.

Dedeoğlu, H.; Şahin, A. E.; Ulusoy, M. \& Ertem, İ. S. (2011). Çocuk Dergileri Üzerine Bir İ̧̧erik Analizi: Bilim Çocuk ve National Geographic Kids. Akdeniz Eğitim Araştırmaları Dergisi, 9, 27-38.

Demiryürek, G. (2012). TRT Çocuk Dergisi'nin Yapısal Özellikler Bakımından Değerlendirilmesi. Kastamonu Eğitim Dergisi, 20 (3), 1017-1034.

Jones, S. C.; Gregory, P. \& Kervin, L. K. (2012). Branded Food References in Children's Magazines: 'Advertisements' are the Tip of the Iceberg. International Journal of Pediatric Obesity, 7 (3), 220-229.

Jones, S. C.; Mannino, N. \& Green, J. (2010). Like Me, Want Me, Buy Me, Eat Me': Relationship-Building Marketing Communications in Children's Magazines. Public Health Nutrition, 13 (12), 2111-2118.

Jones, S. C. \& Reid, A. (2009). Children's Magazines: Reading Resources Or Food Marketing Tools?. Public Health Nutrition, 13 (3), 393-399.

Jones, S. C.; Wiese, E. \& Fabrianesi, B. (2008). Following the Links: Food Advertising and Promotion on Children's Magazine Websites. Journal of Nonprofit \& Public Sector Marketing, 20 (2), 165-190.

Kaptan, A. Y. \& Sürmeli, K. (2011). Çocuk Dergilerinde Karşılaşılan Tipografi Sorunları ve Çözüm Önerileri. inönü Üniversitesi Sanat Ve Tasarım Dergisi, 1(2), 183-197.

Karakaya, Z. (2006). Çocuk Felsefesi ve Çocuk Eğitimi. Din Bilimleri Akademik Araştırma Dergisi VI, 1, 2337.

Karasar, N. (2007). Bilimsel Araştırma Yöntemi. Ankara: Nobel.

Kavcar, C.; Oğuzkan, F. \& Sever, S. (1998). Türkçe Öğretimi, Ankara: Engin.

Kelly, B. \& Chapman, K. (2007). Food References and Marketing to Children in Australian Magazines: A Content Analysis. Health Promotion International, 22(4). 284-291. 
Lindquist J. D. (1979). Children's Attitudes toward Advertising on Television and Radio and in Children's Magazines and Comic Books. In NA - Advances in Consumer Research. 06, eds. 407-412, William L. Wilkie, Ann Abor, Ml: Association for Consumer Research.

Rasul, S. (2013). Borrowing and Code Mixing in Pakistani Children's Magazines: Practices and Functions. Pakistaniaat: A Journal of Pakistan Studies, 5(2), 46-72.

Sert, G.; Kurtoğlu, M.; Akıncı, A. \& Seferoğlu, S. S. (2012). Öğretmenlerin teknoloji kullanma durumlarını inceleyen araştırmalara bir bakış: Bir içerik analizi çalışması. XIV. Akademik Bilişim Konferansı (AB12) Bildirileri, 351-357. Uşak Üniversitesi, Uşak. [Çevrimiçi: http://ab.org.tr/ab12/kitap/sert_kurtoglu_AB12.pdf, Erişim tarihi: 23.09.2015.]

Sever, S. (2012). Çocuk ve Edebiyat. İzmir: Tudem.

Sürmeli, K. (2010). Türkiye'de Eğitim Amaçlı Çocuk Dergilerinde Karşılaşılan Temel Grafik Tasarım Sorunları ve Sorunlara Çözüm Önerileri, Doktora Tezi, On Dokuz Mayıs Üniversitesi, Sosyal Bilimler Enstitüsü, Samsun.

Tanrıkulu, F. (2014). Medya Okuryazarlığı Bağlamında Çocuk Dergileriyle Zenginleştirilmiş Türkçe Dersinin Etkililiği: Bir Eylem Araştırması, Doktora Tezi, Çanakkale Üniversitesi, Eğitim Bilimleri Enstitüsü, Çanakkale.

Tanrı̈̈ğen, A. (2012). Bilimsel Araştırma Yöntemleri. Ankara: Anı.

Ulutaş, A. \& Çaydaş, A. (2013). ileri Yavrutürk Dergisinin Teknoloji Açısından Değerlendirilmesi. The Journal of Academic Social Science Studies International Journal of Social Science, 6(3). 759-771.

Waryncia, L. (2006). Why I Love Children's Magazines. Children and Libraries, 4(3) 40-42.

Yalçın, A. \& Aytaş, G. (2008). Çocuk Edebiyatı. Ankara: Akçağ.

Yıldırım, A. \& Şimşek, H. (2003) Sosyal Bilimlerde Nitel Araştırma Yöntemleri. Ankara: Seçkin.

Yıldız, C.; Okur, A.; Arı, G. \& Yılmaz, Y. (2010). Yeni Öğretim Programına göre Kuramdan Uygulamaya Türkçe Öğretimi. Ankara: Pegem.

Yıldız, Z. (2012). Diyanet Çocuk Dergisinin Din Öğretimi Açısından Değerlendirilmesi. Süleyman Demirel Üniversitesi Sosyal Bilimler Enstitüsü Dergisi, 15, 367-390.

Yiğitbaşı, K. G. (2014).Türkiye'de Çocuk Dergiciliği: TRT Çocuk Dergisi Örneği. Iğdır Üniversitesi Sosyal Bilimler Enstitüsü Dergisi, 5, 37-56.

Zur, D. (2014). Let's go to the Moon: Science Fiction in the North Korean Children's Magazine Adong Munhak, 1956-1965. The Journal of Asian Studies, 73 (2), 327-351.

\section{Diğer Kaynaklar / Outher Sources}

Araştırmacı Çocuk Dergisi, Atlas Çocuk Dergisi, Bilim Çocuk Dergisi, Çamlıca Çocuk Dergisi, Diyanet Çocuk Dergisi, Türkiye Çocuk Dergisi, TRT Çocuk Dergisi. 